\title{
Lithofacies analysis of the Catfish Creek till: Bradtville, Ontario
}

\author{
David H. Huntley \\ Department of Geology, University of New Brunswick, P.O. Box 4400, \\ Fredericton, New Brunswick E3B 5A3, Canada
}

Date Received April 6, 1991

Date Accepted November 21, 1991

\begin{abstract}
Sedimentologic and facies analyses are used to interpret a section of Catfish Creek till at Bradtville, Ontario. Repetitive passive lodgement of debris-rich ice and gradual melt-out beneath active ice produced four massive matrixsupported diamicts $(\mathrm{Dmm})$ separated by sand $(\mathrm{Sg})$ and gravel $(\mathrm{Gm})$ horizons. This sequence was partly reworked by melt-water focused along sand horizons, depositing cross-cutting $\mathrm{Dcm}, \mathrm{Sg}$ and $\mathrm{Gm}$ facies. Post-depositional faulting also occurred. Deposition and glaciofluvial reworking are inferred to have occurred at some distance behind an alternately floated and grounded margin of the late Wisconsinan Erie Lobe.
\end{abstract}

\begin{abstract}
Une approche sédimentologique et une analyse des faciès sont utilisées pour interpréter une coupe du till du ruisseau Catfish à Bradville, en Ontario. La succession de la mise en place passive de glace riche en débris et de la fonte graduelle sous le glacier ont produit quatre diamictons à support par la matrice (Dmm), séparés par des horizons de sable $(\mathrm{Sg})$ et de gravier $(\mathrm{Gm})$. Cette séquence a été en partie remaniée par de l'eau de fonte concentrée le long d'horizons sableux, qui a déposé les faciès discordants $\mathrm{Dcm}, \mathrm{Sg}$ et $\mathrm{Gm}$. Des mouvements de failles postérieurs au dépôt se sont aussi produits. Il est déduit que le dépôt et le remaniement fluvio-glaciaire se seraient produits à une certaine distance de la marge du lobe Erié, du Wisconsinien tardif, laquelle était alternativement flottante et échouée.
\end{abstract}

[Traduit par le journal]

\section{INTRODUCTION}

During the Wisconsinan, southwestern Ontario was the major zone of confluence between the Huron and Erie lobes of the Laurentide ice-sheet (Dreimanis, 1987). In the Bradtville area (Fig. 1a), the Huron Lobe preceded the Erie Lobe deforming the mid-Wisconsinan Tyrconnell Formation as it moved south (Dreimanis, 1987). The composition of the Catfish Creek till, deposited during the mid-late Wisconsinan, reflects interaction between the westward advancing Erie Lobe and the Huron Lobe, flowing south (Hicock and Dreimanis, 1985; Dreimanis et al., 1987). The result of icestream interaction was a southwestward ice flow direction. By the late Wisconsinan, the Erie Lobe had overrun the interlobate zone and the Port Stanley till was deposited (Fig. 1b; Dreimanis et al., 1987).

Evenson et al. (1977) demonstrate that towards Plum Point (Fig. 1a), the Catfish Creek till comprises subaqueous flow tills produced at the margin of a glacier lobe grounded in a glacial lake. Gibbard (1980) and May et al. (1980) recognize that at least part of the Catfish Creek till is the result of basal melt-out. From examination of the Catfish Creek till at Bradtville, Dreimanis et al. (1987) inferred a complex depositional cycle of alternating lodgement, meltout and subglacial debris flows.

To date there is incomplete documentation of all lithofacies types in the Bradtville area. This paper examines a $26 \mathrm{~m}$ section of Catfish Creek till exposed approximately $1 \mathrm{~km}$ northeast of Bradtville (Fig. 1b), in an attempt to improve the working knowledge of depositional processes operating beneath the Erie Lobe during the mid-late Wisconsinan period.

\section{Methodology and Rationale}

Heavy rain and mud flows thwarted numerous efforts to expose the entire section. The composite structure of the section exposed between November 1987 and February 1988 is shown in Figure 2. Non-genetic field descriptions with lithofacies coding (similar to Eyles et al., 1983; Table 1) and sedimentological analysis were employed to describe the section. Graphic logs were drawn at $1 \mathrm{~m}, 13.3 \mathrm{~m}, 17.5 \mathrm{~m}$ and $22.3 \mathrm{~m}$ (Figs. 2, 3). Observed facies relationships were used to propose a depositional environment and facies model.

Various sedimentologic techniques, including analysis of in situ pebble fabrics, granulometric distributions and clast shapes, have been employed to demonstrate glacial transport paths and depositional environments (Boulton, 1978; Sugden et al., 1987). In the Bradtville area, Dreimanis et al. (1987) and others have used lithological content and limestonedolomite ratios to determine stratigraphic relationships of local glacial sequences. These sedimentologic techniques were followed in the present study. 


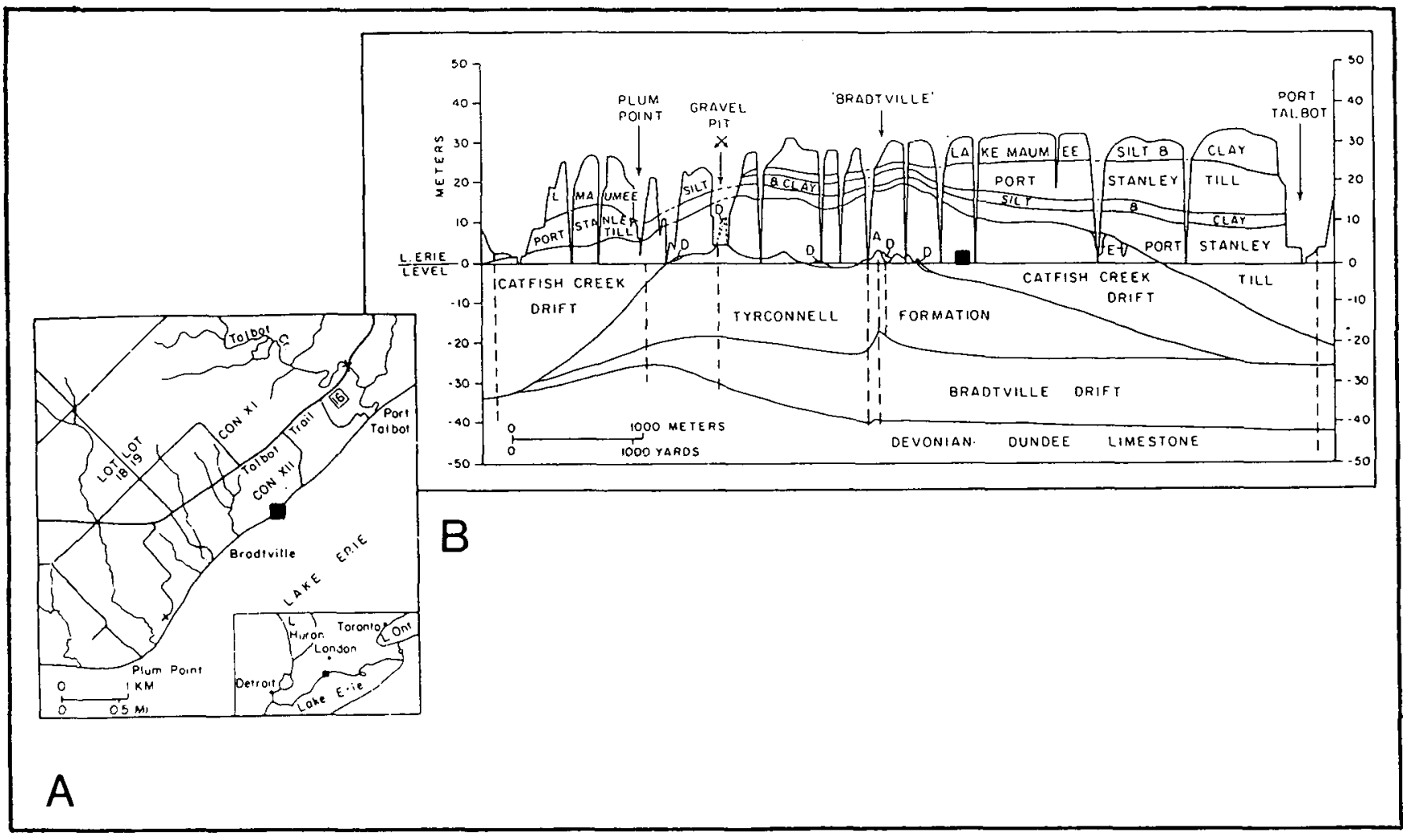

Fig. 1. Location of study. (A) Southwestern Ontario and location of Bradtville. (B) Detailed Stratigraphy from Plum Point to Port Talbot. Black square is location of studied section. Source: modified from Dreimanis (1987).

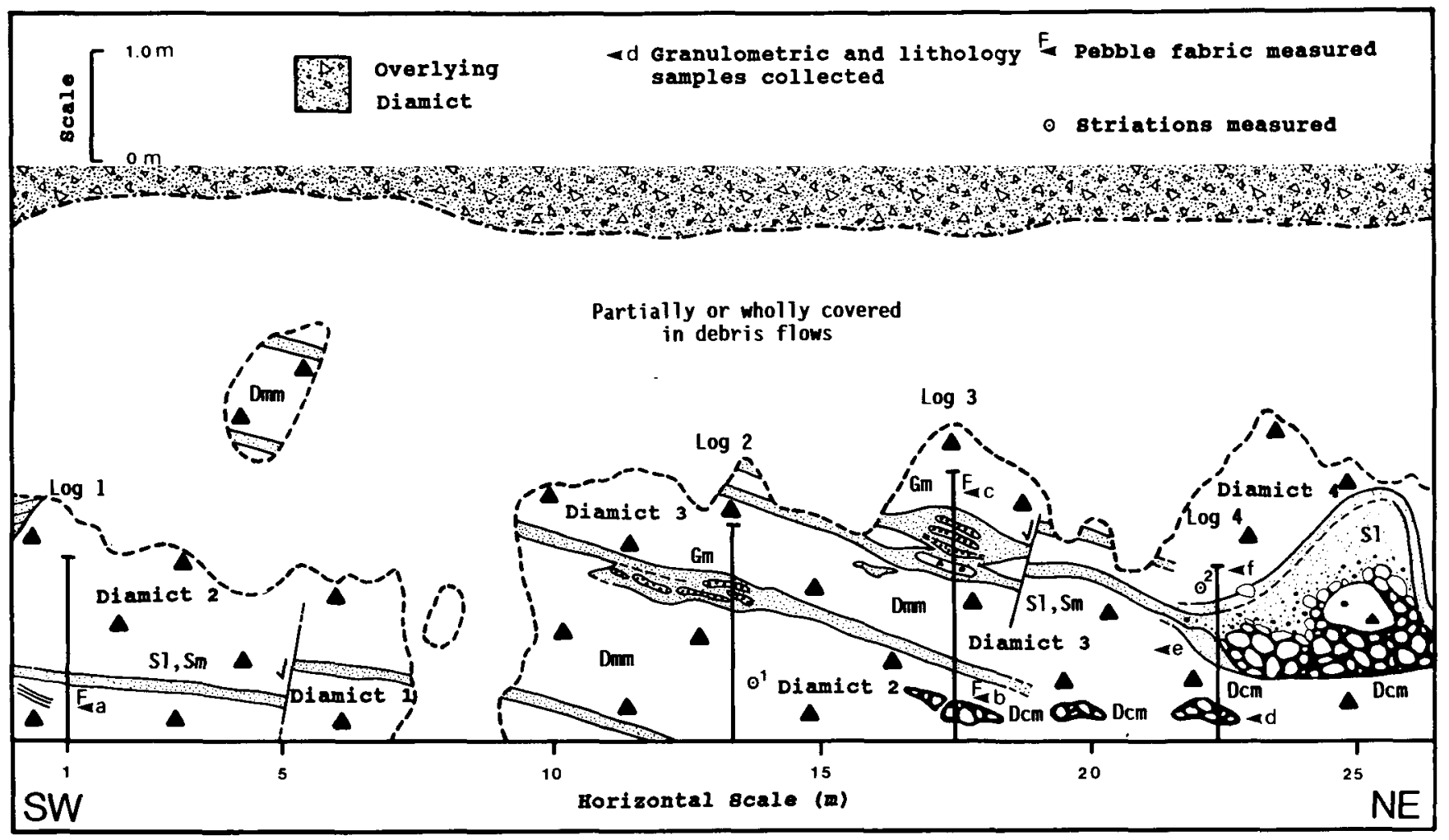

Fig. 2. Location of graphic logs and morphology of section (see Table 1 for lithofacies coding and symbols). 
Table 1. Lithofacies coding and symbols (similar to Eyles $e t$ al., 1983).

\begin{tabular}{|l|l|}
\hline FACIES CODE & SYMBOL \\
Dmm: & Matrix-supported, \\
massive & \\
DCm: $\quad \begin{array}{l}\text { Clast-supported, } \\
\text { massive }\end{array}$ & \\
Sand and gravel & \\
Sm: $\quad$ Massive & \\
Sl: $\quad$ Laminated & \\
Sg: $\quad$ Sand and gravel & graded \\
Gm: $\quad$ Massive gravel
\end{tabular}

Two-dimensional pebble fabrics were recorded on 50-80 in situ prolate pebbles (Drake, 1974) at sample points a-c (Fig. 2). In addition, striae orientations were measured on pebble surfaces at sample locations 1 and 2 (Fig. 2).

From sample points a-f (Fig. 2), $1 \mathrm{~kg}$ samples of matrix were collected for analysis. Granulometric analysis was performed on $100 \mathrm{~g}$ portions of crushed matrix (less than $5 \Phi)$. Results were first plotted as cumulative curves to evaluate statistical distributions, then presented for comparative purposes as a particle-size frequency graph (Fig. 4). Quantitative gasometric (Chittick) analysis was also carried out on $0.85 \mathrm{~g}$ fractions of matrix (Dreimanis, 1962). Results are compared with carbonate contents of local stratigraphic units in Table 2 (Dreimanis et al., 1987).

In addition, 300 pebbles were collected for lithologic content and clast shape analysis between sample locations af (Fig. 2). Table 2 compares present results to reported lithologic contents of stratigraphic units (Dreimanis et al., 1987). The a, b and c-axes of 50 clasts were measured and plotted on Zinng charts for qualitative assessment of particle shape. Those clasts showing signs of post-depositional shatter were excluded from evaluation.

\section{Stratigraphy and Description of Lithofacies}

Lithofacies observed within the section are described below in stratigraphic order.
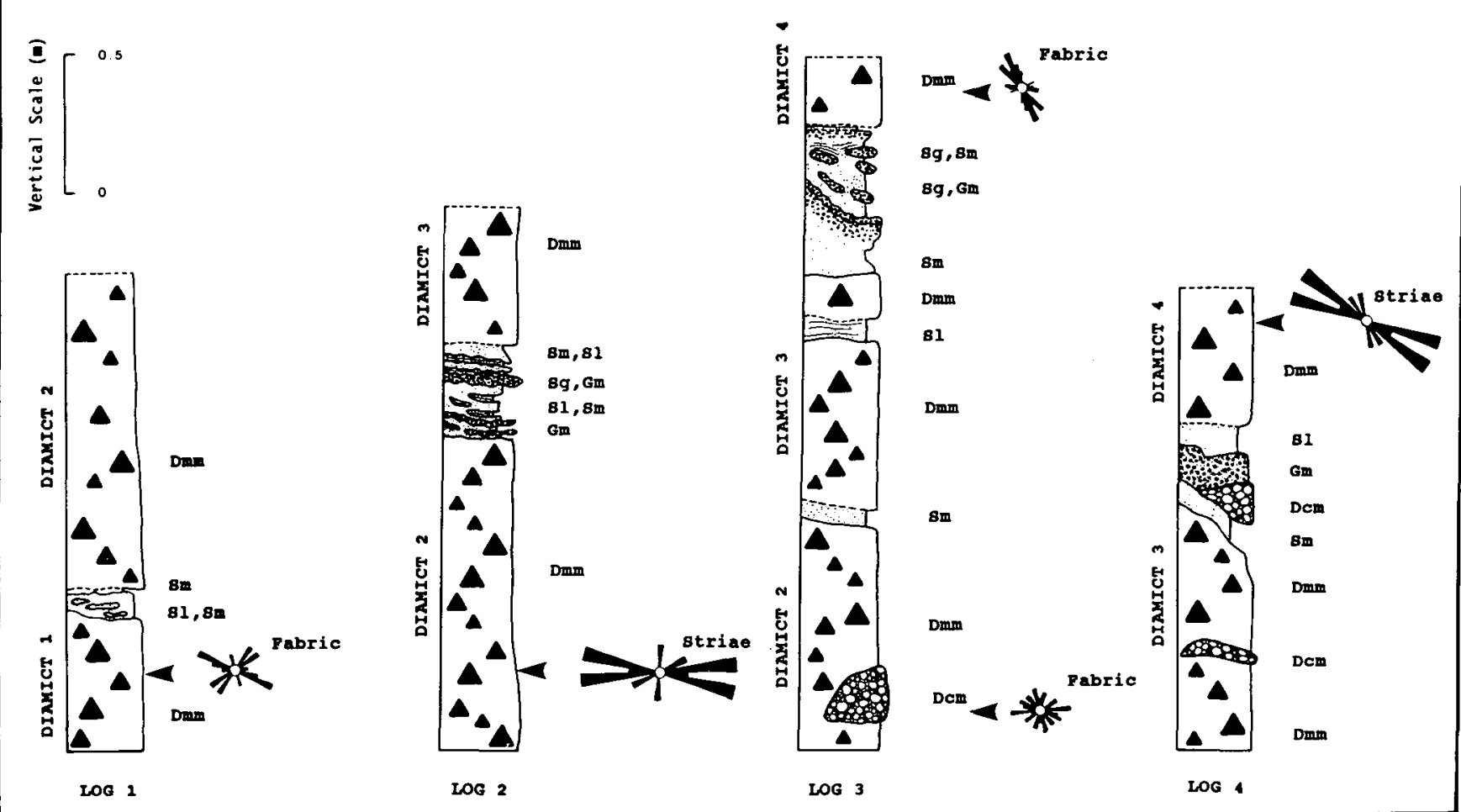

Fig. 3. Graphic log profiles (see Table 1 for lithofacies coding and symbols). 


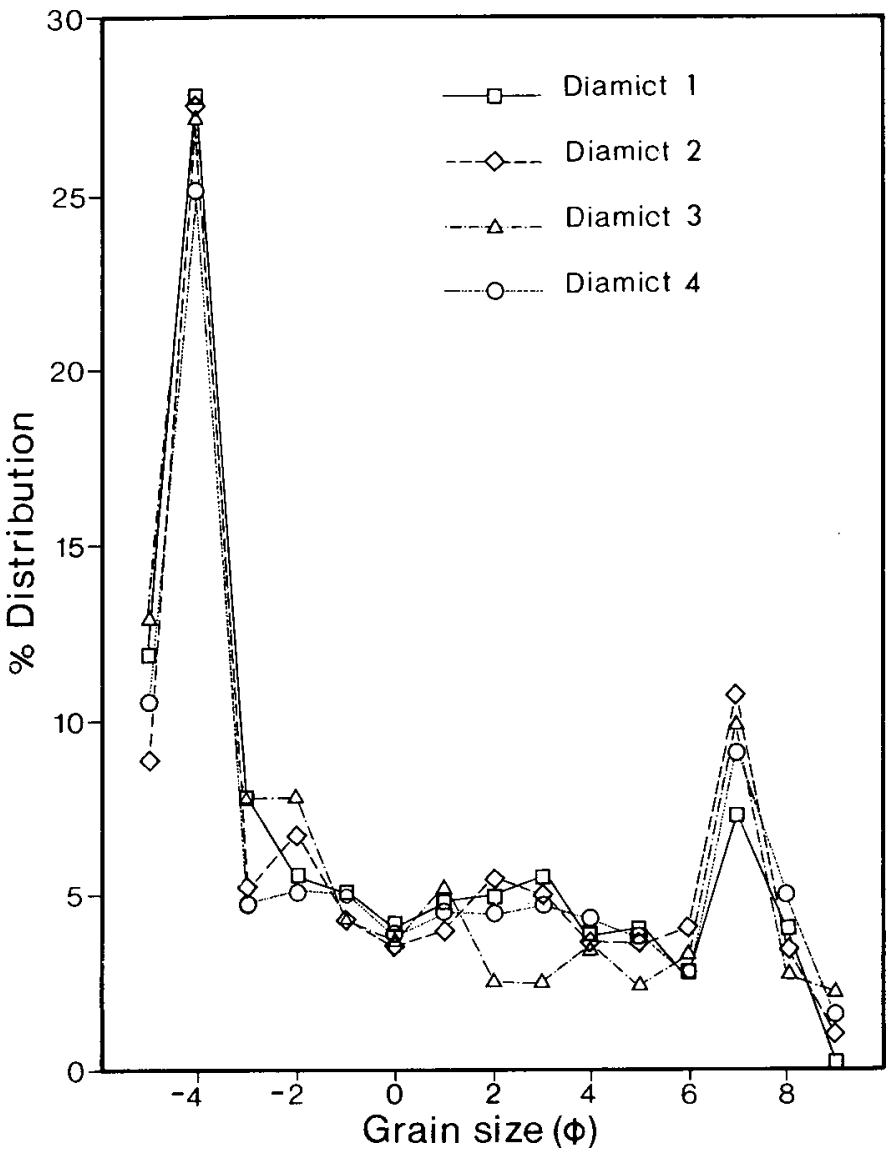

Fig. 4. Granulometric analysis for Diamicts 1-4.

\section{Massive, matrix-supported diamict (Dmm)}

Four diamict units are recognized (Diamicts 1-4; Figs. 2, 3). These range in thickness from $0.8 \mathrm{~m}$ (Diamict 3 ) to $2.0 \mathrm{~m}$ (Diamict 2). Estimated thickness of Diamicts 1 and 4 are not possible since bases and tops are poorly exposed.

Diamicts 1-4 are predominantly massive, polymictic matrix-supported diamicts (Dmm). The dominant lithologies are limestone and dolostone, accounting for between 50 and $63 \%$ of counted clasts (Table 2; Diamicts 1 and 4, respectively). Clasts are predominantly spheroidal or prolate, although faceted striated boulders are present.

Fabric orientations are variable. Diamict 1 shows a dominant trend at WNW-ESE (dominant) and a minor NESW trend (Fig. 3). Fabric measurements were not recorded in Diamicts 2 and $3(\mathrm{Dmm})$. However, the principal orientation in Diamict 4 is strongly unimodal at $315^{\circ}$. Striae orientations on faceted clasts in Diamict 2 indicate a W-E flow direction. In contrast, striae recorded in Diamict 4 suggest NW-SE flow.

Granulometric distributions of Diamicts $1-4$ are all bimodal, with strong peaks at $-4 \Phi$ and $+7 \Phi$ (Fig. 4). There is little apparent deviation between these units. Mean calcite/ dolomite ratios (Table 2) range from 1.23 (Diamict 3) to 1.63 (Diamict 1).

\section{Sandy lithofacies (Sm, SI)}

Dmm units are separated by three massive and laminated sand units $(\mathrm{Sm}, \mathrm{Sl})$, dipping at $15^{\circ}$ to $18^{\circ} \mathrm{SE}$. They range in thickness from under $10 \mathrm{~cm}(\log 1)$ to $80 \mathrm{~cm}(\log 3)$.

Within the sandy units, $\mathrm{Sm}$ is characteristically interbedded with Sl, and contacts are planar and non-erosional. The lower boundary with each diamict is erosional and fissility is noted within Sm units above this transition. This fissility parallels the local dip of the sand units. The upper transition with Dmm units is always gradational. Quantitative assessment of most sedimentologic properties of the sand units is lacking. Carbonate analysis, however, yields a low calcite/ dolomite ratio of 0.4 .

Massive clast-supported diamict (Dcm), sandy gravels $(\mathrm{Sg})$ and gravels $(\mathrm{Gm})$

Both diamict (Dmm) and sand units (Sm, Sl) are crosscut by lensoid clast-supported diamicts (Dcm), graded sandy gravels $(\mathrm{Sg})$ and massive gravels $(\mathrm{Gm})$. Five $\mathrm{Dcm}$ deposits are recognized in the section (Fig. 2). Although Dcm units were not studied in detail, they appear to comprise polymictic assemblages lithologically similar to Dmm units, although depleted in matrix. Fabrics recorded at sample point $\mathrm{d}(\mathrm{Di}$ amict 2; Fig. 3), indicate a random orientation.

$\mathrm{Sg}, \mathrm{Gm}$ units display complex bedding relationships, with repetitive erosive contacts between Sm, Sl horizons. Intraformational discontinuities between $\mathrm{Sg}$ and $\mathrm{Gm}$ beds are also observed in Logs 2 and 3 (Fig. 3). However, $\mathrm{Sg}$ and $\mathrm{Gm}$ units are intimately associated with Dcm lenses.

\section{Other features}

All units are cross-cut by minor high angle normal faults, dipping northwest. The described sequence is also overlain by a massive, non-faulted diamict (Fig. 2). This latter unit was not examined in this study.

\section{INTERPRETATION OF LITHOFACIES}

\section{Massive, matrix-supported diamict (Dmm) and sandy lithofacies (Sm, SI)}

The presence of faceted striated clasts, bimodal sediment peaks at $-4 \Phi$ and $7 \Phi$ and preferred pebble fabric alignment imply Diamicts 1-4 (Dmm) have a basal glacigenic origin (Boulton, 1978; Sugden et al., 1987). In addition, stratigraphic relationships (Fig. 1b), clast content and calcite/dolomite ratios of Diamicts 1-4 (Table 2) indicate an association with the Catfish Creek till. However, the origin of the Diamicts 1-4 is unclear.

The repetitive nature of diamict and sand units could have been generated by imbricate thrusting of a single diamict. Thus, the erosional basal contacts between Dmm and Sm may represent planes of décollement (Croot, 1987; Tsui 
Table 2. Comparison of lithologic and carbonate content of Diamicts 1-4 with other local tills. Additional data from Dreimanis et al. (1987).

\begin{tabular}{|c|c|c|c|c|c|c|}
\hline \multirow[t]{2}{*}{ Unit } & \multicolumn{4}{|c|}{ Pebble Lithology (\%) } & \multirow{2}{*}{$\begin{array}{c}\mathrm{CaCO}_{3} / \mathrm{MgCO}_{3} \\
\text { Range }\end{array}$} & \multirow{2}{*}{$\begin{array}{l}\text { Ratio } \\
\text { Mean }\end{array}$} \\
\hline & Limestone & Dolostone & Clastics & Igneous & & \\
\hline Diamict 1 & 34 & 16 & 21 & 26 & $1.32-1.94$ & 1.63 \\
\hline Diamict 2 & 40 & 19 & 18 & 23 & $1.12-1.48$ & 1.30 \\
\hline Diamict 3 & 38 & 18 & 31 & 13 & $1.06-1.40$ & 1.23 \\
\hline Diamict 4 & 42 & 21 & 27 & 10 & $1.60-3.07^{*}$ & 1.60 \\
\hline Sand (Sm) & & & & & 0.4 & \\
\hline \multicolumn{7}{|l|}{ Catfish } \\
\hline Creek till & 38 & 26 & 16 & 18 & 1.1 & \\
\hline Dunwich till & 24 & 46 & 13 & 28 & 0.3 & \\
\hline \multicolumn{7}{|l|}{ Upper } \\
\hline Bradtville till & 47 & 7 & 30 & 11 & 2.5 & \\
\hline
\end{tabular}

* Contaminated value

et al., 1988). Fissility in the Sm units may have been imparted during thrusting. However, the absence of plastic deformation, intra-formational faulting and fissility within Dmm suggest diamicts were emplaced passively. Therefore, thrusting is rejected as a means of generating the observed sequence.

Alternatively, the sequence may have been produced by repetitive passive lodgement of debris-rich ice sheets (Boulton, 1971). In this scenario, emplacement would have occurred when the force imparted by ice flow was insufficient to maintain the forward motion of debris-rich basal ice (Hallet, 1981; Kaszycki, 1987). Thus, deposition occurred gradually by in situ melting of debris-rich ice (Shaw, 1982, 1985).

To this end, the transitional upper contacts between Sm, Sl and Dmm may represent preserved primary ice structure (Sugden et al., 1987). The passive nature of emplacement would also ensure that primary granulometric distributions and pebble fabrics would be preserved (Sugden et al., 1987). The shift in fabric and striae orientation may indicate a change in ice-flow direction between emplacement of $\mathrm{Di}$ amicts 1-2 and Diamict 4. Fissility and the non-conformable basal contacts between Sm and Dmm may result from fluid movement and erosion during dewatering and consolidation of emplaced diamicts. The low calcite/dolomite ratio in the sandy facies (Table 2) suggest syn- and post-depositional melt-water removed fines and calcite (Hallet, 1979). However, post-glacial groundwater leaching could also have altered the carbonate content of these units.

Massive clast-supported diamict (Dcm), sandy gravels $(\mathrm{Sg})$ and gravels $(\mathrm{Gm})$

Depleted matrix in the Dcm lenses could have resulted from winnowing. Imbrication was not noted, but upward- fining was observed. These observations indicate fluvial action. In addition, Dcm lenses cross-cut both Dmm and Sm, SI facies, indicating that they post-date deposition of these units. This implies either a glaciofluvial origin (Eyles et al., 1982) or deposition by lodgement clustering (Drewry, 1986). The latter interpretation is rejected because of the absence of deformation structures elsewhere in Diamicts 1-4. Thus, a glaciofluvial origin is favoured. To this end, lensoid Dcms are interpreted as till-walled melt-water channels (C.C. Smart, personal communication, 1988).

Contacts between gravel $(\mathrm{Gm})$, sandy gravel $(\mathrm{Sg})$ and $\mathrm{Sm}, \mathrm{Sl}$ horizons are erosional. Both $\mathrm{Gm}$ and $\mathrm{Sg}$ members occur in close proximity to $\mathrm{Dcm}$ lenses and appear to be derived from these deposits. These observations indicate that after emplacement of Diamicts 1-4, glaciofluvial reworking occurred and $\mathrm{Dcm}, \mathrm{Gm}$ and $\mathrm{Sg}$ units were deposited. Although most water flow was apparently directed through Dcm units, there may have been additional water movement between Diamicts 1-4, focused through the $\mathrm{Sl}$ and Sm horizons.

\section{Discussion}

The sedimentologic data and field relationships indicate that the sequence is associated with the Catfish Creek till. Thus, this sequence may be correlated with waterlain sequences southwest of the section towards Plum Point (Fig. 1). The facies and depositional models proposed below (Figs. 4, 5) are based on relationships between lithofacies described in this paper and observations of adjacent exposures.

\section{Facies model}

In a local context, all depositional processes are believed to occur some distance behind the WNW-flowing Erie Lobe. 


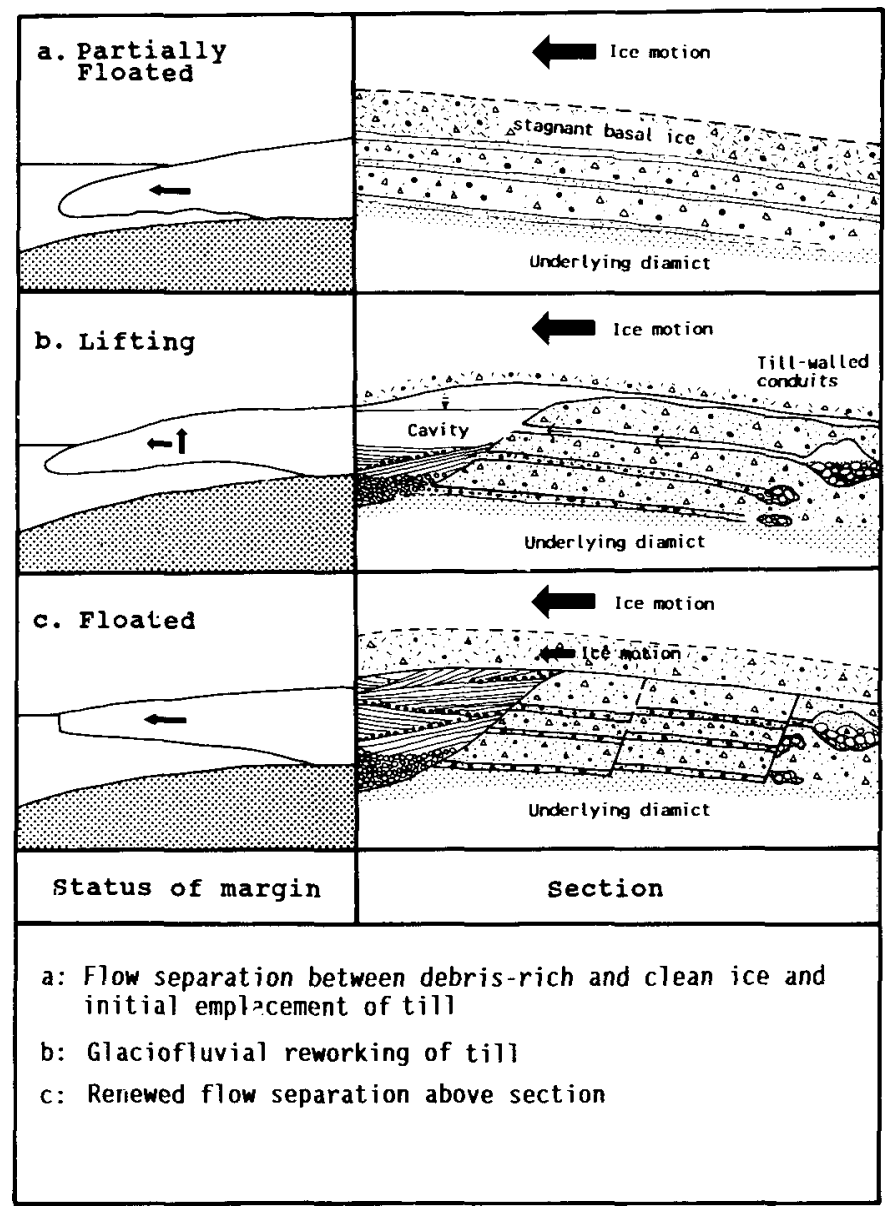

Fig. 5. Depositional model for section. Left column describes inferred condition of glacier margin, southwest of section. Right column describes processes occurring at section related to marginal conditions.
This lobe was periodically grounded near Plum Point (Figs. 1, 6; Evenson et al., 1977; May et al., 1980). Fluctuation between a grounded and floating margin could have caused contrasting extensional and compressional flow regimes behind this margin. This alternation is believed to be responsible for the sedimentary sequence described below (Fig. 5ac).

Ice advance initiated the repetitive passive lodgement of sheets of basal ice (Fig. 5a). Particle-size distribution, pebble shape characteristics, fabric orientation and striation patterns within the Dmm units are similar to those expected from basal ice (Boulton, 1978; Sugden et al., 1987). From these observations, it is inferred that the glacier was transporting basal (Dmm) and traction zone (Sl, Sm) debris and that emplacement was facilitated by passive lodgement (Boulton, 1971). Subsequent deposition occurred by melt-out beneath actively flowing ice (Fig. 5a; Shaw, 1985).

The trigger for initial emplacement may relate to ice margin dynamics and basal conditions at the site. Flow separation between slow-moving basal ice and faster moving debris-free ice (Hallet, 1981) may have occurred if the Erie Lobe was partially floated and experiencing extending flow (Fig. 5a; Drewry, 1986). This separation would have left a stagnant debris-rich basal zone beneath actively sliding ice (Fig. 5a; Kaszycki, 1987). The stacked nature of diamicts could be accounted for by cyclical patterns of floating (and extending flow) and grounding (with compressional flow).

Dcm lenses cross-cut Dmm and Sl, Sm units. Their morphology and sedimentology are reminiscent of till-walled glacio-fluvial channels. Some $10 \mathrm{~m}$ west of the section, repetitive sequences of gravels fining into cross-bedded sands were apparently deposited within a large cavity. Loading structures indicate that these sediments were partially water-

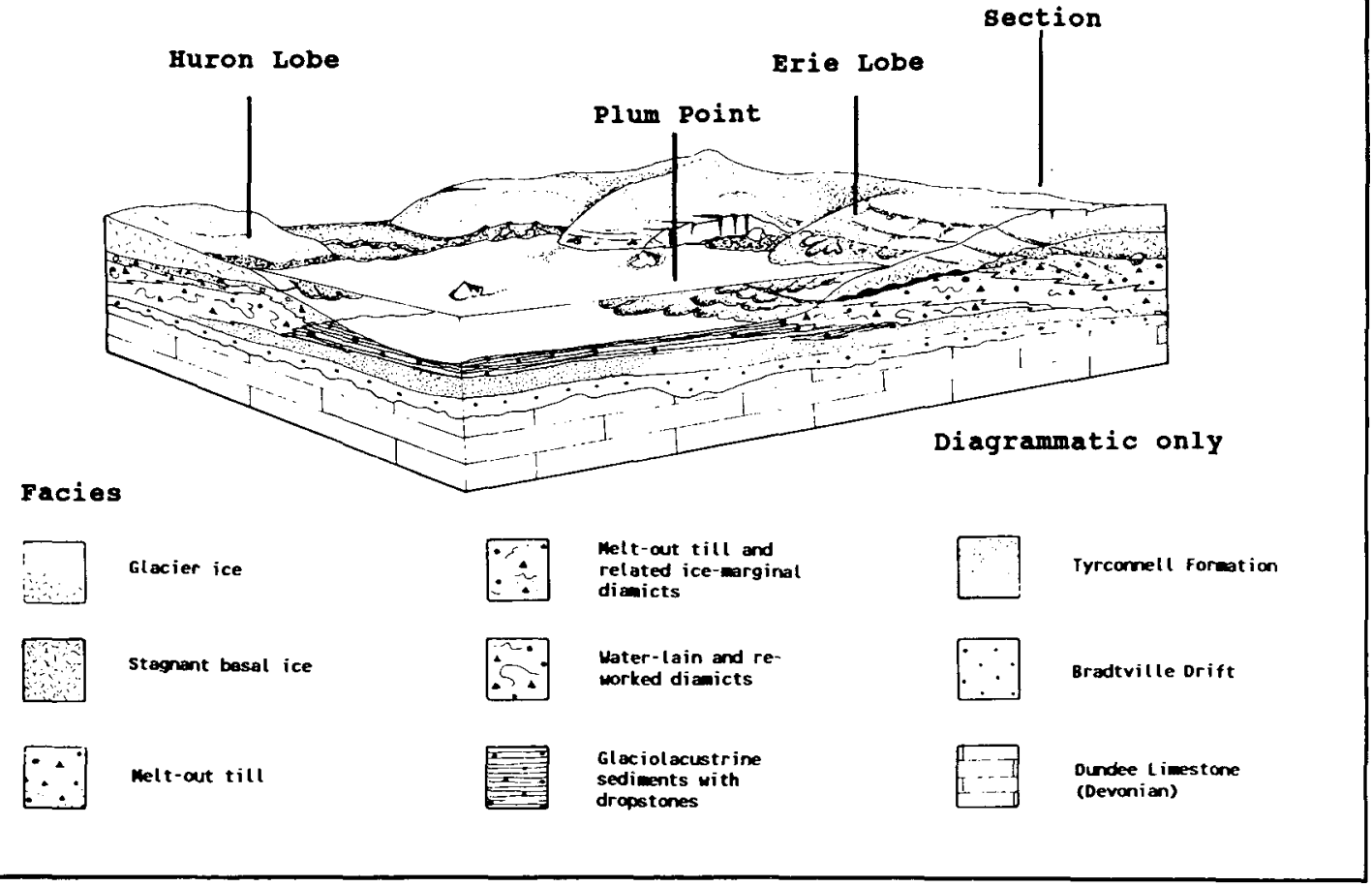

Fig. 6. Possible environment of deposition and facies relationships in the Bradtville area during the mid-late Wisconsinan. Viewer perspective looking toward the northeast. 
saturated after deposition. These observations indicate another change in depositional conditions. This implies that after flow separation and emplacement of till, glaciofluvial activity increased (Fig. 5b). The trigger for this change is uncertain, but may be related to the melting of stagnant basal ice and seasonal melt-water availability. Favourable hydraulic gradients, facilitating water movement, would have been provided locally by the presence of the cavity (Walder, 1986). The origin of the cavity may have been related to the lifting of the glacier margin (Fig. 5b).

Erosional contacts between sand $(\mathrm{Sl}, \mathrm{Sm})$ and gravel and sandy gravel ( $\mathrm{Gm}$ and $\mathrm{Sg}$ ) may be attributable to water flow at this time. Since the permeability of diamicts would have been too low to provide a primary transport route for escaping water, preferred flow paths were likely sought through sand horizons between diamict units. Sediment-laden water, derived from conduits, may thus have been routed through these horizons (cf. Broster, 1991), eroding sand and depositing Gm and $\mathrm{Sg}$ facies (Fig. 5b).

Both the diamict units and sand units are cross-cut by minor normal faults which do not extend into the overlying unit (Fig. 5c). Their orientation is transverse to regional ice flow and displacement direction indicates post-depositional extensional forces affecting the sequence. Faulting may represent late glacio-tectonic disruption related to ice flow above the sequence (Fig. 5c). Alternatively, faults may indicate post-depositional soft-sediment collapse related to loss of supporting matrix ice (cf. Broster and Clague, 1987).

The sharp contrast between this sequence and the overlying massive diamict suggests another change in the depositional regime. However, the origin of this unit is beyond the scope of the present discussion.

\section{Conclusions}

The section described at Bradtville apparently has a complex depositional history. According to the model presented, deposition was controlled by ice-marginal dynamics near Plum Point, Ontario. Diamict units were passively lodged and subsequently reworked by sediment-laden conduit waters during melt-out. In a local context, the units represent part of a subglacial lodgement/melt-out lithofacies assemblage which passes gradationally into ice-marginal and ultimately glaciolacustrine deposits towards Plum Point (Fig. 6).

\section{ACKNOWLEDGEMENTS}

I would like to thank Lisa Law, Cindy Blacklock, Catherine Rowley, Robert Heipel, Jim Syrotuik and Dave Meers for their encouragement and assistance at various stages. Constructive comments came from Dr. B.E. Broster, Dr. A. Dreimanis, Dr. S.R. Hicock and Dr. C.C. Smart. Critical reviews and suggested improvements were provided by $A$. A. Seaman and an anonymous reader.

Boulton, G.S. 1971. Till genesis and fabric in Svalbard, Spitzbergen. In Till: A symposium. Edited by R.P. Goldth- wait. Columbus, Ohio State University Press, pp. 41-72.

1978. Boulder shapes and grain size distributions of debris as indicators of transport paths through a glacier and till genesis. Sedimentology, 25, pp. 773-799.

Broster, B.E. 1991. Glacitectonic deformation in sediment and bedrock, Hat Creek, British Columbia. Géographie physique et Quatemaire, 45, pp. 5-20.

Broster, B.E. and Clague, J.J. 1987. Advance and retreat glacigenic deformation at Williams Lake, British Columbia. Canadian Journal of Earth Sciences, 24, pp. 1421-1430.

Croot, D.G. 1987. Glacio-tectonic structures: a mesoscale model of thin-skinned thrust sheets? Journal of Structural Geology, 9. pp. 797-808.

DraKe, I.D. 1974. Fabric control by clast shape. Geological Society of America Bulletin, 85, pp. 247-250.

Dreimanis, A. 1962. Quantitative gasometric determination of calcite and dolomite using Chittick apparatus. Joumal of Sedimentary Petrology, 32, pp. 520-529.

1987. The Port Talbot Interstadial Site, Southwestern Ontario. Geological Society of America Centennial Field Guide, NE Section, pp. 345-348.

Dreimanis, A., Hamilton, J.P., and Kelly, P.E. 1987. Complex subglacial sedimentation of Catfish Creek Till at Bradtville, Ontario, Canada. Inqua Symposium on Genesis and Lithology of Glacial Deposits, Balkema, Rotterdam, pp. 73-87.

Drewry, D. 1986. Glacial Geologic Processes. Edward Amold, $270 \mathrm{p}$.

Evenson, E.B., Dreimanis, A., and Newsome, J.W. 1977. Subaquatic flow tills: a new interpretation for the genesis of some laminated till deposits. Boreas, 6, pp. 115-133.

Eyles, N., Sladen, J.A., and Gilroy, S. 1982. A depositional model for stratigraphic complexes and facies superimposition in lodgement tills. Boreas, 11, pp. 317-333.

Eyles, N., Eylses, C.H., and Miall, A.D. 1983. Lithofacies types and vertical profile models; an alternative approach to the description and environmental interpretation of glacial diamict and diamictite sequences. Sedimentology, 30, pp. 393-410.

Gib bard, P. 1980. The origin of stratified Catfish Creek Till by basal melting. Boreas, 9, pp. 71-85.

Hallet, B. 1979. Subglacial regelation water film. Joumal of Glaciology, 23, pp. 321-333.

1981. Glacial abrasion and sliding: their dependence on the debris concentration in basal ice. Annals of Glaciology, 2, pp. 23-28.

Hicock, S.R. and Dreimanis, A. 1985. Glaciotectonic structures as useful ice-movement indicators in glacial deposits: four Canadian case studies. Canadian Journal of Earth Sciences, 22, pp. 339-346.

KAsZYCKI, C.A. 1987. A model for glacial and proglacial sedimentation in the shield terrane of southern Ontario. Canadian Journal of Earth Sciences, 24, pp. 2373-2391.

May, R.W., Dreimanis, A., and Stanowski, W. 1980. Quantitative evaluation of clast fabrics within the Catfish Creek Till, Bradtville, Ontario. Canadian Journal of Earth Sciences, 17. pp. 1064-1074.

SHAW, J. 1982. Melt-out till in the Edmonton area, Alberta, Canada. Canadian Journal of Earth Sciences, 19, pp. 15481569.

1985. Subglacial and ice marginal environments. In Glacial Sedimentary Environments. Edited by G.M. Ashely, J. Shaw, and N.D. Smith. Society of Economic Palaeontologists 
and Mineralogists, SEPM Short Course 16, pp. 7-84.

Sugden, D., Clapperton, C.M., Gemmell, J.C., and Knight, P.G. 1987. Stable isotopes and debris in basal glacier ice, South Georgia, Southern Ocean. Journal of Glaciology, 33 . pp. 324-329.
Tsui, P.C., Cruden, D.M., and Thompson, S. 1988. Ice-thrust terrains and glaciotectonic settings in central Alberta. Canadian Journal of Earth Sciences, 26, pp. 1308-1318.

WALDER, J.S. 1986. Hydraulics of subglacial cavities. Journal of Glaciology, 32, pp. 439-445. 